\title{
Türkiye'deki bazı orkide türlerinin mineral besin elementi ve ağır metal konsantrasyonları
}

\author{
Kürşat KORKMAZ ${ }^{(i)}$, Sevda TÜRKIŞฺ ${ }^{(i)}$ \\ ${ }^{1}$ Ordu Üniversitesi, Ziraat Fakültesi, Toprak Bilimi ve Bitki Besleme Bölümü, Ordu \\ ${ }^{2}$ Ordu Üniversitesi, Eğitim Fakültesi, Matematik ve Fen Bilgisi Eğitimi Bölümü, Ordu
}

Alınış tarihi: 20 Ekim 2020, Kabul tarihi: 4 Ocak 2021

Sorumlu yazar: Kürşat KORKMAZ, e-posta: korkmaz60@gmail.com

Öz

Amaç: $\mathrm{Bu}$ çalışmada, altı orkide türünün yumrusundaki mineral besin elementi ( $\mathrm{N}, \mathrm{P}, \mathrm{K}, \mathrm{Ca}$, $\mathrm{Mg}, \mathrm{S}, \mathrm{Fe}, \mathrm{Cu}, \mathrm{Zn}, \mathrm{Mn}$ ve B) ve ağır metal (Co, $\mathrm{Cr}$, Ni ve Cd) seviyeleri standart analitik metotlar kullanılarak belirlenmiștir.

Materyal ve Yöntem: Bu çalıșmada bitki materyali olarak Orchis purpurea Huds. subsp. purpurea, Orchis provincialis Balb. ex Lam.\& DC., Orchis coriophora L. subsp. coriophora, Ophrys oestifera M. Bieb. subsp. oestifera, Ophrys sphegodes Mill. subsp. caucasica (Woronow ex Grossheim) Soo,Orchis laxiflora subsp. laxiflora Lam kullanılmıștır. Orkide örnekleri Türkiye'nin Karadeniz bölgesinde yer alan Bartın ilinden toplanarak element analizine tabi tutulmuştur.

Araștırma Bulguları: Seçilen bu bitkilerin, makro element konsantrasyonları $(\mathrm{N}, \mathrm{P}, \mathrm{K}, \mathrm{Ca}, \mathrm{Mg}$ ve $\mathrm{S})$ ortalaması, sırasıyla \% 0,86-1.97; \% 0.14-0.23; \% $1.16-3.38 ; \% 1.01-1.24 ; \% 0,17-0,47$ ve $\% 0,12-0,18$ olarak bulundu. Mikro element konsantrasyonları ( $\mathrm{Fe}, \mathrm{Cu}, \mathrm{Zn}, \mathrm{Mn}$ ve B) sirasiyla, 254-428 mg kg-1, 7.87$16.88 \mathrm{mg} \mathrm{kg}^{-1}, 20-38 \mathrm{mg} \mathrm{kg}^{-1}, 22-58 \mathrm{mg} \mathrm{kg}^{-1}$ ve $14-39$ mg kg-1 olarak bulundu. Ayrıca numunelerin ağır metal konsantrasyonları, (Co, $\mathrm{Cr}$, Ni ve $\mathrm{Cd}$ ), sirasiyla, $0.19-0.54 \mathrm{mg} \mathrm{kg}^{-1}, 0.41-0.90 \mathrm{mg} \mathrm{kg}{ }^{-1}, 0.61-1.59 \mathrm{mg}$ $\mathrm{kg}^{-1}, 0.005-0.026 \mathrm{mg} \mathrm{kg}^{-1}$ olarak belirlenmiştir.

Sonuç: Mineral besin elementleri ve ağır metal konsantrasyonu bitkiden bitkiye değişiklik göstermiștir. Element analizleri, seçilmiș orkide türlerinin kayda değer seviyelerde besin elementi içerdiğini göstermiştir. Orchis provincialis ve Ophyrs oestifera'nın besin elementi konsantrasyonu diğer bitkilerinkinden daha yüksek olarak saptanmıştır. Bu sonuçlar, orkide türlerinin incelenen mineral besinler açısından zengin olduğunu, ayrıca ağır metal konsantrasyonlarının kritik seviyelerin altındaki konsantrasyonlarda olduğunu göstermektedir.

Anahtar kelimeler: ağır metaller, mineral besin elementi, orkide türleri, orkide yumrusu

\section{Mineral nutrient and heavy metal concentrations of some orchid species in Turkey}

\begin{abstract}
Objective: In this study, levels of mineral nutrients $(\mathrm{N}, \mathrm{P}, \mathrm{K}, \mathrm{Ca}, \mathrm{Mg}, \mathrm{S}, \mathrm{Fe}, \mathrm{Cu}, \mathrm{Zn}, \mathrm{Mn}$ and $\mathrm{B}$ ) and heavy metal $(\mathrm{Co}, \mathrm{Cr}, \mathrm{Ni}$ and $\mathrm{Cd}$ ) in tuber of six orchids species were determined using standard analytical methods.
\end{abstract}

Materials and Methods: Orchis purpurea Huds. subsp. purpurea, Orchis provincialis Balb. ex Lam.\& DC., Orchis coriophora L. subsp. coriophora, Ophrys oestifera M. Bieb. subsp. oestifera, Ophrys sphegodes Mill. subsp. caucasica (Woronow ex Grossheim) Soo,Orchis laxiflora subsp. laxiflora Lam were used as plant material in this study. The samples of orchid were collected from Bartın city at Black Sea region in Turkey and subjected to nutrient analysis.

Results: Average of macro element concentrations (N, P, K, Ca, Mg and S) of these selected plants were found $0.86-1.97 \%$; $0.14-0.23 \%$; $1.16-3.38 \%$; 1.01 $1.24 \% ; 0.09-0.20 \%$ and $0.12-0.18 \%$, respectively. Microelement concentrations ( $\mathrm{Fe}, \mathrm{Cu}, \mathrm{Zn}, \mathrm{Mn}$ and $\mathrm{B}$ ) were found 254-428 $\mathrm{mg} \mathrm{kg}^{-1}, 7.87-16.88 \mathrm{mg} \mathrm{kg}^{-1}, 20$ $38 \mathrm{mg} \mathrm{kg}^{-1}, 22-58 \mathrm{mg} \mathrm{kg}^{-1}$ and $14-39 \mathrm{mg} \mathrm{kg}^{-1}$,

Korkmaz, K., \& Türkiș, S. (2021). Türkiye'deki bazı orkide türlerinin mineral besin elementi ve ağır metal konsantrasyonları. Akademik Ziraat Dergisi, 10(1), 137-144. 
respectively. Also, heavy metal concentrations (Co, $\mathrm{Cr}, \mathrm{Ni}$ and $\mathrm{Cd}$ ) of the samples were determined 0.19$0.54 \mathrm{mg} \mathrm{kg}^{-1}, 0.41-0.90 \mathrm{mg} \mathrm{kg}^{-1}, 0.61-1.59 \mathrm{mg} \mathrm{kg}^{-1}$, 0.005-0.026 mg kg-1, respectively.

Conclusion: Concentration of mineral nutrients and heavy metal varied from plant to plant. Elemental analysis of the samples indicated that these selected orchid species contained appreciable levels of nutrient. Nutrient status of Orchis provincialis and Ophyrs oestifera were higher than those of other plants. These results suggest that the orchid species was rich in the investigated mineral nutrients, also heavy metal concentration was found to be at concentrations low the critical levels.

Keywords: heavy metals, mineral nutrient, orchid species, orchid tuber

\section{Giriş}

Türkiye, bitki gen kaynakları açısından üç bitki coğrafyası bölgelerinin (Avrupa-Sibirya, Akdeniz ve İran-Turan) kesişme noktasında yer alması nedeniyle oldukça zengin biyolojik çeşitliliğe sahiptir (Palaz ve ark., 2018). Türkiye'de doğal olarak yetişen 12.000 'den fazla bitki taksonu olup, bunların yaklaşık 3649'u endemik taksonlardan oluşmaktadır (Güner ve ark., 2012). Orchidaceae familyası bu zengin biyolojik çeșitlilik içinde ayrı bir yere sahiptir ve ülkemizde Muğla, Milas, Isparta, Antalya, Kahramanmaraş, Van, Kastamonu, Taşköprü ve Safranbolu'da yaygın olarak yetişmektedir (Baytop 1999). Çiçekli bitkilerin en büyük ve en çeşitlisi Orchidaceae familyasıdır. Çeşitli kaynaklara göre değişmekle birlikte bu familya içinde 900 cins ve 20 000 türün tanımlandığı, ayrıca $70 \quad 000$, bazı kaynaklara göre $100 \quad 000$ orkide hibridinin bulunduğu ve her yll 800 yeni orkide türünün tanımlandığı; tür sayısının $30 \quad 000^{\prime} \mathrm{e}$ kadar çıkabileceği bildirilmektedir (Erzurumlu ve Sögüt, 2012). Türkiye'de 24 cinse ait toplam 204 orkide türünün yetiștiği bildirilmiștir (Arabacı ve ark., 2017). Orkideler ekosistemlerde ihtiyaç duydukları optimum koşullarda ve belirli alanlarda gelişebilirler. Bir ekosistemde orkidelerin bulunması, ekosistemin iyi çalıştı̆̆ının bir göstergesidir. Bir ekosistemin sağlı̆ıının bozulması konusunda erken uyarı sistemi sağlayarak koruyucu önlemlerin herhangi bir gecikme olmaksızın alınmasına imkan verir (Laroche ve ark., 2012). Bu durum kirlilik göstergesi olmalarını da sağlamaktadır. Dünyada gıda alanında, parfüm eldesinde ve tıbbi amaçlarla kullanılan orkideler çoğu bölgede tehlike altındadır (Hürkan ve ark., 2019). Ayrıca süs bitkisi olarak da orkideler sektörde değerli bir yere sahiptir. Orkide türlerinin $\% 85$ 'inden salep yumrusu elde edilmektedir (Yaman, 2012). Salep bitkisi genellikle dondurma yapımında kullanılan veya sıcak içecek olarak değerlendirilen bir üründür. Son yllarda, insanlar sağlıklı beslenebilmek için karbonhidratlar, proteinler, vitaminler, çeșitli antioksidan bileşikler ve mineral besin elementlerince zengin gidaları tüketme eğilimindedirler. Makro ve mikro elementler de bitki ve insan yaşamı için önemli olan kimyasal elementler olup bunlarm belirli seviyelerde tüketilmesi gerekmektedir. Ancak, ihtiyaç duyulan düzeylerde alınmadıklarında, bu elementlerin bir kısmı yararlı iken bir kısmı ise toksik olup, eksikliğinde ve fazlalığında olumsuz etkiler ortaya çıkmaktadır.

Günümüzde, hızlı endüstrileşme ve sanayileşme sonucu, pek çok tıbbi bitki şehirlere ya da sanayi bölgelerine yakın yerlerden toplanmakta ve ağır metal ya da diğer olası zararlı madde içerikleri kontrol edilmeden tüketiciye ulaşmaktadır (Petrova ve ark., 2011, Sekeroglu ve ark., 2008). Ayrıca bu kontrolsüz toplamalar içerdiği besin elementlerinin ve ağır metal içeriklerinin bilinmemesi nedeniyle de insan sağlığı açısından önemli bir risk oluşturmaktadır. A ̆ğır metallerin yol açtığı çevresel kirlenme dünya genelinde ciddi bir sorun olmakla birlikte, günümüz sanayi toplumlarında bu kirlenmeyi önlemek pek fazla mümkün olamamaktadır. Kirlilik riski olan bölgelerden toplanan tıbbi bitkiler son kullanıcıya ulaştırılana kadar pek çok işlemden geçmekte ve bazen kontaminasyon olmaktadır (Korkmaz ve ark., 2010). $\mathrm{Bu}$ bitkiler, diğer gıda ürünlerine nazaran $\mathrm{az}$ miktarlarda tüketilmekle birlikte, yüksek oranda ağır metal içermeleri durumunda, sürekli kullanımlarda sağlık üzerine olumsuz etki gösterebilmektedir (Yaldız ve Şekeroğlu 2013). Orkide türlerinin mineral kompozisyonları ve ağır metaller içeriklerinin belirlenmesi gıda güvenliği ve insan sağlığı açısından oldukça önemlidir. Bu konudaki tehlikenin boyutu ve olası risklerin ortaya koyulması da bu anlamada oldukça önemlidir. Ancak, orkide türlerine ait bu konuda çok fazla çalışmaya rastlanılmamıştır. Bu amaçla yürütülen araştırmada, altı orkide türünün yumrusundaki mineral besin elementi ve ağır metal seviyeleri standart analitik metotlar kullanılarak belirlenmiștir. 


\section{Materyal ve Metot}

$\mathrm{Bu}$ çalışmada, altı orkide türünün yumrusundaki mineral besin elementi ( $\mathrm{N}, \mathrm{P}, \mathrm{K}, \mathrm{Ca}, \mathrm{Mg}, \mathrm{S}, \mathrm{Fe}, \mathrm{Cu}, \mathrm{Zn}$, $\mathrm{Mn}$ ve $\mathrm{B})$ ve ağır metal $(\mathrm{Co}, \mathrm{Cr}, \mathrm{Ni}$ ve $\mathrm{Cd}$ ) seviyeleri standart analitik metotlar kullanılarak belirlenmiştir.

Bitki materyalleri Orchis purpurea Huds. subsp. purpurea, Orchis provincialis Balb. ex Lam.\& DC., Orchis coriophora L. subsp. coriophora, Ophrys oestifera M. Bieb. subsp. oestifera, Ophrys sphegodes Mill. subsp. caucasica (Woronow ex Grossheim) Soo,Orchis laxiflora subsp. laxiflora Lam türlerinden oluşmaktadır (Çizelge 1). Bitki materyalleri 20132014 yılları arasında Batı Karadeniz Bölgesinde bulunan Bartın İli Orduyeri Mahallesi mevkisinde çayırlık ve çalılık bölgelerinden toplanmıştır. Bartın ili Avrupa Sibirya fitocoğrafik bölgesinin Öksin provensinde, Davis'in kareleme sistemine göre A4 bölgesinde bulunmaktadır (Davis, 1965-1988). Bitki türlerinin teşhislerinde Davis' in "Flora of Turkey and the East Aegean Islands" Vol. 1-9 (Davis, 196596 1985), Vol. 10 (Davis vd., 1988) ve Vol. 11 (Güner vd., 2000) eserleri kullanılmıștır. Orkide türlerinde bitkilerde yumru kök aksamı toprak altında birlikte bulunduğundan esas kullanılan yumru, aksamından kökler ayrılmış ve yumru aksamı analize alınmıștır. Orkide yumruları bulaşmanın önlenmesi için ön yıkama işlemine tabi tutularak toprak ve çeşitli partiküllerden temizlenmiştir. Bitki numuneleri etüvde $65^{\circ} \mathrm{C}^{\prime}$ de 48 saat kurutulduktan sonra agat taşlı bitki değirmeninde ögütülerek analize hazır hale getirilmiştir. Ögütülen bitki örnekleri nitrik asit $\left(\mathrm{HNO}_{3}\right)$ ile mikro dalga firında (MarsXpress CEM) çözünürleştirilerek, makro element $(\mathrm{P}, \mathrm{K}, \mathrm{Ca}, \mathrm{Mg}$, ve $\mathrm{S})$ ve mikro element $(\mathrm{Fe}, \mathrm{Cu}, \mathrm{Zn}, \mathrm{Mn}$ ve $\mathrm{B})$ ve ağır metal (Co, $\mathrm{Cr}$, Ni ve $\mathrm{Cd}$ ) konsantrasyonları, ICP-OES cihazında tespit edilmiştir (Kacar ve İnal, 2010). Bitki örneklerinde N analizi Kjeldahl yöntemine göre yapılmıştır (Bremmer, 1965).

\section{Araştırma Bulguları ve Tartışma}

Orkide türlerine ait makro element konsantrasyonları Çizelge 2, mikro element konsantrasyonları Çizelge 3 ve ağır metal konsantrasyonları Çizelge 4' te sunulmuştur. Farklı orkide türlerine ait yumruların element konsantrasyonları incelendiğinde, makro element konsantrasyonları (N, P, K, Ca, Mg ve S) ortalaması, sirasiyla \% 0,.86-1.97; \% 0.14-0.23; \% 1.16-3.38; \% 1.01-1.24; \% 0,09-0,20 ve \% 0,12-0,18 arasinda değișiklik göstermiștir (Çizelge 2). En yüksek N konsantrasyonu \%1.97 ile Orchis provincialis türünde saptanırken, en düşük \%0.86 ile Ophyrs sphegodes subsp. caucasica türünde belirlenmiştir. Bitkilerde azot proteinler, amino asitler, nükleik asitler, enzimler, klorofil, ATP, ADP gibi birçok önemli organik bileşiklerin yapısında yer almaktadır. (Bolat ve Kara, 2017). Orkide yumrularına ait $P$ değerleri incelendiğinde, en yüksek $P$ konsantrasyonu \%0.23 ile Orchis provincialis türünde saptanırken, en düşük $\% 0.14$ ile Ophyrs sphegodes subsp. caucasica türünde belirlenmiştir. Bitki gelişiminde fosfor, ATP, şekerler ve nükleik asitler, enerji transferi yapan ATP'nin ve genetik özellikleri belirleyen DNA'nın oluşumu için gereklidir (Korkmaz ve ark., 2009). Bitki örneklerinde $\mathrm{K}$ değerleri incelendiğinde, en yüksek K konsantrasyonunun \%3.38 ile Orchis provincialis türünde saptanırken, en düşük \%1.16 ile Ophyrs sphegodes türünde olduğu belirlenmiştir. Potasyum bitkilerde tohumda depolanmaktadır ve bitkilerde 200 den fazla enzimin yapısında yer almasının yanı sıra bitkilerde su dengesi ve fotosentez ürünlerinin taşınmasında oldukça etkilidir (Yazıcı ve Korkmaz, 2020). Bitki örneklerinde $\mathrm{Ca}$ analiz sonuçları incelendiğinde, en yüksek $\mathrm{Ca}$ konsantrasyonun $\% 1.24$ ile Ophyrs oestifera türünde olduğu saptanırken, en düşük \%1.01 Ophyrs sphegodes subsp. caucasica türünde olduğu belirlenmiştir. Bitkilerde de Ca'un büyük bir bölümü, kalsiyum pektatlar şeklinde hücre duvarlarının oluşumunda yer alır ve bitki dokularının güçlenmesinde temel görev üstlenmiştir (Kırlı ve ark., 2019, Singh, 2020). Bitki örneklerinde $\mathrm{Mg}$ değerleri incelendiğinde, en yüksek $\% 0.47$ ile Orchis provincialis türünde saptanırken, en düşük \%0.17 ile Ophyrs sphegodes türünde olduğu belirlenmiştir. Bitkilerde klorofil molekülünün yapıtaşı olmasıyla en başta fotosentez ve fizyolojik ve biyokimyasal reaksiyonda görev alan, bitkiler için son derece önemli olan ve bitkilere mutlak gerekli bir makro besin elementidir (Özkutlu ve ark., 2016). Bitki örneklerinde S değerleri incelendiğinde, en yüksek $\% 0.18$ ile Orchis provincialis türünde saptanırken, en düşük \%0.12 ile Ophyrs sphegodes subsp. caucasica ve Orchis purpurea türlerinde olduğu belirlenmiștir. Kükürt tüm canlı organizmalar için temel bir elementtir. Sistein ve methionin aminoasitleri kükürt (S) içeren aminoasitlerdir ve peptidlerin yapısında $S$ atomları disülfit bağlarının oluşturulmasında görev almaktadır (Tonguç ve ark., 2017). 
Çizelge 1. Araştırma alanında yer alan türlerin latince adları, koordinat ve yükseklik değerleri.

\begin{tabular}{|c|c|c|}
\hline Türün Adı & Koordinat & Yükseklik \\
\hline Orchis purpurea Huds. subsp. purpurea & 413'41.67" K 3220'41.75" D & $93 \mathrm{~m}$ \\
\hline Orchis provincialis Balb. ex Lam.\& DC. & 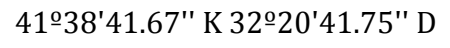 & $93 \mathrm{~m}$ \\
\hline Orchis coriophora L. subsp. coriophora & 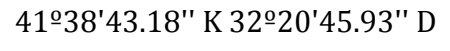 & $90 \mathrm{~m}$ \\
\hline Orchis laxiflora subsp. laxiflora Lam & $41^{\circ} 38^{\prime} 44.07$ " K 3220'30.73" D & $108 \mathrm{~m}$ \\
\hline Ophrys oestifera M. Bieb. subsp. oestifera & $41^{\circ} 38^{\prime} 41.67^{\prime \prime} \mathrm{K} 32^{\circ} 20^{\prime} 41.75^{\prime \prime} \mathrm{D}$ & $93 \mathrm{~m}$ \\
\hline Ophrys sphegodes Mill. subsp. caucasica (Woronow ex Grossheim) Soo & $41^{\circ} 38^{\prime} 41.67^{\prime \prime}$ K 3220'41.75" D & $93 \mathrm{~m}$ \\
\hline
\end{tabular}

Çizelge 2. Orkide türlerinin makro element konsantrasyonları

\begin{tabular}{llccccc}
\hline & $\mathrm{N}$ & $\mathrm{P}$ & $\mathrm{K}$ & $\mathrm{Ca}$ & $\mathrm{Mg}$ & $\mathrm{S}$ \\
& & & $\%$ & & & \\
\hline Orchis purpurea & 1.47 & 0.07 & 1.56 & 1.21 & 0.22 & 0.12 \\
Orchis provincialis & 1.97 & 0.23 & 3.38 & 1.13 & 0.47 & 0.18 \\
Orchis coriophora & 0.98 & 0.16 & 1.52 & 1.04 & 0.19 & 0.14 \\
Ophyrs oestifera & 1.37 & 0.22 & 2.05 & 1.24 & 0.31 & 0.18 \\
Ophyrs sphegodes subsp. caucasica & 0.86 & 0.14 & 1.16 & 1.01 & 0.17 & 0.12 \\
Orchis laxiflora & 1.27 & 0.16 & 1.79 & 1.07 & 0.24 & 0.13 \\
\hline
\end{tabular}

Çizelge 3. Orkide türlerinin mikro element konsantrasyonları

\begin{tabular}{lccccc}
\hline & $\mathrm{Fe}$ & $\mathrm{Cu}$ & $\begin{array}{c}\mathrm{Zn} \\
(\mathrm{mg} \mathrm{kg}-1)\end{array}$ & $\mathrm{Mn}$ & $\mathrm{B}$ \\
\hline Orchis purpurea & & & 25 & 24 & 39 \\
Orchis provincialis & 379 & 8 & 38 & 30 & 29 \\
Orchis coriophoro & 428 & 17 & 21 & 41 & 14 \\
Ophyrs oestifera & 405 & 8 & 33 & 24 & 23 \\
Ophyrs sphegodes subsp. caucasica & 353 & 12 & 20 & 22 & 20 \\
Orchis laxiflora & 365 & 9 & 26 & 58 & 20 \\
\hline
\end{tabular}

Çizelge 4. Orkide türlerinin ağır metal konsantrasyonları

\begin{tabular}{lllll}
\hline & $\mathrm{Co}$ & $\mathrm{Cr}$ & $\mathrm{Ni}$ & $\mathrm{Cd}$ \\
\hline Orchis purpurea & & \multicolumn{2}{c}{ (mg kg-1) } & 0.025 \\
Orchis provincialis & 0.54 & 0.81 & 1.54 & 0.026 \\
Orchis coriophoro & 0.47 & 0.80 & 1.08 & 0.014 \\
Ophyrs oestifera & 0.25 & 0.82 & 1.11 & 0.005 \\
Ophyrs sphegodes subsp. caucasica & 0.22 & 0.90 & 1.59 & 0.013 \\
Orchis laxiflora & 0.52 & 0.79 & 1.18 & 0.015 \\
\hline
\end{tabular}


Konuyla ilgili yeterli literatür bulunmamasına rağmen sınırlı sayıda yapılan çalışmalarda Topçuoğlu ve ark. (1996) 30 farklı orkide yumrusunda yaptıkları analiz sonuçlarına göre $\mathrm{N}$, konsantrasyonlarının \%0.83-4.35, Tekinşen ve Güner (2010) \%0.56-0.86, Arabacı ve ark., (2017) ise \%1.82-2.63 arasında değiștiğini belirtirken, Palaz ve ark., (2018) orkide yumrusunda besin elementi konsantrasyonlarını \%0.17 P, \%0.73 K, \%0.15 Ca ve $\% 0.07 \mathrm{Mg}$ olarak belirtmişlerdir. Tatiya ve ark. (2018) ise Eulophia herbacea Lindl. yumrularında yaptıkları analizlerde \%0.92 N, \%2.48 K, \%1.71 Ca ve $\% 2.48 \mathrm{Mg}$ olduğunu belirtmişlerdir. Tıbbi bitkilerde yapılan çalışmalarda kenevir tohumlarında makro element $(\mathrm{N}, \mathrm{P}, \mathrm{K}, \mathrm{Ca}, \mathrm{Mg}$ ve $\mathrm{S})$ konsantrasyonlarının sirasiyla, \%1.41-3.28, \%0.11$0.54, \% 0.63-2.85, \% 0.75-4.64, \% 0.15-0.65$ ve $\% 0.15$ 0.47 olduğunu belirtmişlerdir. Özcan ve ark., (2013) baklagil tohumlarıyla yürüttükleri çalışmada makro element ( $\mathrm{P}, \mathrm{K}, \mathrm{Ca}, \mathrm{Mg}$ ve $\mathrm{S}$ ) konsantrasyonlarını sirasiyla, \%0.27-0.58, \%0.74-1.65, \%1.38-2.78, \%0.21-0.28 ve \%0.14-0.32 olarak bildirmișlerdir. Esetlili ve ark. (2014) 18 farklı tıbbi aromatik bitkilerde yürüttükleri çalışmada makro element $(\mathrm{N}$, $\mathrm{P}, \mathrm{K}, \mathrm{Ca}$ ve $\mathrm{Mg}$ ) konsantrasyonlarını sırasıyla, \%0.574.80, \%0.07-0.93, \%0.6-1.65, 50.3-1.54 ve \%0.060.26 olarak belirlemişlerdir. Bu sonuçlar, elde edilen çalışma sonuçlarıyla benzerlik göstermektedir.

Araştırma sonuçları incelendiğinde, mikro element konsantrasyonları (Fe, Cu, Zn, Mn ve B) 254-428 mg $\mathrm{kg}^{-1}, 7.87-16.88 \mathrm{mg} \mathrm{kg}^{-1}, 20-38 \mathrm{mg} \mathrm{kg}^{-1}, 22-58 \mathrm{mg} \mathrm{kg}^{-1}$ ve 14-39 mg $\mathrm{kg}^{-1}$ olarak belirlenmiştir. Fe konsantrasyonu incelediğimiz bitki türlerinde diğer elementlere daha yüksek olarak belirlenmiştir. Orkide türlerinde en yüksek Fe miktarı $428 \mathrm{mg} \mathrm{kg}^{-1}$ ile Orchis provincialis türünde belirlenirken, en düşük $254 \mathrm{mg} \mathrm{kg}^{-1}$ ile Orchis laxiflora türünde elde edilmiştir. Tatiya ve ark. (2018) ise Eulophia herbacea Lindl. yumrularında yaptıkları analizlerde bu türlerin $\mathrm{Fe}$ konsantrasyonlarının yüksek olduğunu ve orkide yumrularında $164 \mathrm{mg} \mathrm{kg}^{-1} \mathrm{Fe}$ bulunduğunu belirtmişlerdir. Palaz ve ark. (2018) orkide bitkisinde Fe konsantrasyonunu 117.6 mg kg 1 olarak bulmuşlardır. Yapılan analiz sonuçları test edilen orkide türlerinin $\mathrm{Fe}$ açısından zengin olduğunu göstermektedir. Bitkilerde Fe, DNA sentezi, solunum ve fotosentez gibi metabolik süreçlerde kritik rol oynadığı için hemen hemen tüm canlı organizmalar için gerekli bir mikro besin elementidir ve ayrıca, birçok metabolik yol demir tarafından aktive edilir ve birçok enziminin yapısında bulunur
(Rout ve Sahoo., 2015). Orkide türlerinde en yüksek Cu miktarı 17 mg kg-1 $^{-1}$ Orchis provincialis türünde belirlenirken, en düşük $8 \mathrm{mg} \mathrm{kg}^{-1}$ ile Orchis purpurea, Orchis coriophora, Orchis laxiflora türlerinde elde edilmiştir. $\mathrm{Bu}$ değerler test edilen orkide türlerinin $\mathrm{Cu}$ açısından zengin olduğunu gösterirken, konuyla ilgili olarak Palaz ve ark. (2018) orkide bitkisinde $\mathrm{Cu}$ konsantrasyonunu $4.1 \mathrm{mg} \mathrm{kg}^{-1}$ olarak bulmuşlardır. Orkide türlerinde en yüksek Zn miktarı 38 mg kg-1 ile Orchis provincialis türünde belirlenirken, en düşük $20 \mathrm{mg} \mathrm{kg}^{-1}$ ile Ophyrs sphegodes subsp. caucasica türünde elde edilmiştir. Bitkilerde klorofil üretimi, solunum ve protein sentezleri için bitki tarafından gerek duyulan bir bitki besin elementi olan $\mathrm{Cu}$, çeşitli oksidaz enzimlerinde aktivasyonu, çok sayıdaki elektron transferi ve karbonhidrat metabolizmasindan da sorumludur (Bolat ve Kara, 2017). Konuyla ilgili olarak yürütülen çalışmalarda, orkide türlerinde $\mathrm{Zn}$ konsantrasyonu 13.9 mg kg-1 olarak belirlenmiştir (Palaz ve ark. 2018). Canlılar için önemli bir besin elementi olan Zn'nun bitkilerde 300 den fazla enzimin yapısında ve birçok biokimyasal reaksiyonda önemli bir rolü olduğu bilinmektedir (Korkmaz ve ark., 2015). Orkide türlerinde en yüksek Mn miktarı $41 \mathrm{mg} \mathrm{kg}^{-1}$ ile Orchis coriophoro türünde belirlenirken, en düşük $22 \mathrm{mg}$ $\mathrm{kg}^{-1}$ ile Ophyrs sphegodes subsp. caucasica türünde elde edilmiştir. Mangan (Mn, manganez) bitki büyümesinde temel bir elementtir ve bitkilerde birçok biyokimyasal işlemde rol oynar ki esas olarak fotosentez, lipid biyosentezi ve oksidatif stres gibi temel işlemlerde kofaktör olarak görev yapar, ayrıca enzimlerin yapısal bileşenleri olan $\mathrm{Cu}, \mathrm{Zn}, \mathrm{Fe}$ ve Mo gibi diğer iz elementlerin aksine $\mathrm{Mn}$ genellikle bir enzim aktivatörüdür ve başka metal iyonları ile değiştirilebilir durumdadır (Sevilmiş ve ark., 2020). Orkide türlerinde en yüksek B miktarı $39 \mathrm{mg} \mathrm{kg}^{-1}$ ile Orchis purpurea türünde belirlenirken, en düşük 14 mg kg-1 ile Orchis coriophoro türünde elde edilmiştir. Bitkilerde fenolik bileşiklerin ve nükleik asit sentezinde, karbonhidrat ve protein metabolizmasında, şekerlerin taşınmasında, hücre duvarı sentezinde ve yapısında, ligninleşmede, oksin metabolizmasında, polen çimlenmesinde ve polen tüpünün gelişiminde önemli işlevler üstlenmektedir (Yazıcı ve Korkmaz, 2020). Konuyla ilgili yeterli literatür bulunmaması nedeniyle farklı tıbbi ve aromatik bitkilerde yürütülen çalışmalarda Ergün ve ark. (2010) mikro element ( $\mathrm{Fe}, \mathrm{Cu}, \mathrm{Zn}$ ve $\mathrm{Mn}$ ) konsantrasyonlarını sırasıyla, 27.3-1542.7 mg kg-1, $0.8-17.0 \mathrm{mg} \mathrm{kg}^{-1}, 1.42-47.3 \mathrm{mg} \mathrm{kg}^{-1}$ ve $6.8-244.2 \mathrm{mg}$ $\mathrm{kg}^{-1}$ ve Esetlili ve ark. (2014) 59-689 mg kg-1, 1.8- 
$19.3 \mathrm{mg} \mathrm{kg}^{-1}, 12-79 \mathrm{mg} \mathrm{kg}^{-1}, 7-122 \mathrm{mg} \mathrm{kg}^{-1}, 7.3-67.3$ $\mathrm{mg} \mathrm{kg}^{-1}$ arasında değiștiğini belirtmișlerdir. Korkmaz ve ark. (2010) kenevir tohumlarında $98-121 \mathrm{mg} \mathrm{kg}^{-1}$ $\mathrm{Fe}, 9-12 \mathrm{mg} \mathrm{kg}^{-1} \mathrm{Cu}, 70-102 \mathrm{mg} \mathrm{kg}^{-1} \mathrm{Mn}, 46-65 \mathrm{mg} \mathrm{kg}-$ ${ }^{1} \mathrm{Zn}$ ve $13-14 \mathrm{mg} \mathrm{kg}^{-1} \mathrm{~B}$ olduğunu belirtmiştir. Rajan ve ark. (2014) ise benzer şekilde farklı tıbbi aromatik bitkilerde mikro element $(\mathrm{Fe}, \mathrm{Cu}, \mathrm{Zn}$ ve $\mathrm{Mn})$ konsantrasyonlarını sirasıyla $33.7-308.5 \mathrm{mg} \mathrm{kg}^{-1}$, $3.5-10.7 \mathrm{mg} \mathrm{kg}^{-1}, 7.9-18.2 \mathrm{mg} \mathrm{kg}^{-1}$ ve $17.8-79.3 \mathrm{mg} \mathrm{kg}$ 1 arasında değiştiğini bildirmişlerdir. Bu sonuçlar, elde edilen çalışma sonuçlarıyla benzerlik göstermektedir.

Orkide yumrularına ait ağır metal konsantrasyonları (Co, Cr, Ni ve Cd), sırasiyla, $0.19-0.54 \mathrm{mg} \mathrm{kg}^{-1}, 0.41$ $0.90 \mathrm{mg} \mathrm{kg}^{-1}, 0.61-1.59 \mathrm{mg} \mathrm{kg}^{-1}, 0.005-0.026 \mathrm{mg} \mathrm{kg}^{-1}$ olarak belirlenmiştir (Çizelge 4). Çalışma kapsamındaki bitkilerin tamamı değerlendirildiğinde eser miktarda ağır metaller konsantrasyonlarına sahip olduğu görülmektedir. Araştırma sonuçlarına göre en yüksek Co konsantrasyonu $0.54 \mathrm{mg} \mathrm{kg}^{-1}$ Orchis purpurea bitkisinde, $\mathrm{Cr}$ konsantrasyonu 0.90 mg kg-1 ile Ophyrs oestifera, Ni konsantrasyonu en yüksek $1.59 \mathrm{mg} \mathrm{kg}^{-1}$ ile Ophyrs oestifera ve $\mathrm{Cd}$ konsantrasyonu en yüksek $0.026 \mathrm{mg} \mathrm{kg}^{-1}$ ile Orchis provincialis türünde bulunmuştur. Orkide yumrularına ait ağır metal konsantrasyonları (Co, Cr, $\mathrm{Ni}$ ve Cd), Korkmaz ve ark. (2010) tarafından diğer tıbbi ve aromatik bitkiler için belirtilen kritik sınır değerlerin oldukça altında gözükmektedir. Konuyla ilgili yeterli literatür bulunmaması nedeniyle farklı tıbbi ve aromatik bitkilerde yürütülen çalışmalarda $\mathrm{Co}, \mathrm{Cr}$, Ni ve Cd konsantrasyonlarının, Ozcan ve ark., (2013) yürüttükleri çalışmada $0.00-0.76 \mathrm{mg} \mathrm{kg}^{-1}$, $0.41-3.75 \mathrm{mg} \mathrm{kg}^{-1}, 1.58-11.70 \mathrm{mg} \mathrm{kg}^{-1}$ ve $0.00-0.15$ mg $\mathrm{kg}^{-1}$ ve Okut (2019) 9 farklı tıbbi bitkide yürüttüğü araştırmada ağır metal konsantrasyonlarını sırasıyla, $0.015 \mathrm{mg} \mathrm{kg}^{-1} \mathrm{Ni}, 0.00$ $0.03 \mathrm{mg} \mathrm{kg}^{-1} \mathrm{Cd}, 0.002-0.111 \mathrm{mg} \mathrm{kg}^{-1} \mathrm{Cr}$ ve $0.01-0.09$ mg kg-1 Co olarak belirtmişlerdir. Bu çalışmada var olan sonuçlar diğer tıbbi bitkilerde belirtilen ağır metal değerleriyle benzerlik göstermektedir.

\section{Sonuç}

Orkide bitkisinin yumrularında mineral besin elementi ve ağır metal miktarları hakkında literatürde ayrıntılı bilgiye rastlanılmadığından, bu bitkinin içerdiği bitki besin maddelerinin yeterlik düzeyi net bir şekilde değerlendirilemese de, orkide bitkisinin yumrularının mineral beslenme düzeylerinin diğer tıbbi aromatik bitkilere yakın olduğu söylenebilir. Araştırma sonuçlarına göre Orchis provincialis ve Ophyrs oestifera'nın besin elementi konsantrasyonlarının diğer test edilen bitkilerden daha yüksek olduğu belirlenmiştir. Ayrıca, bu orkide türlerinin yumrularının $\mathrm{K}$ ve $\mathrm{Fe}$ açısından zengin olduğu belirlenmiş olup ağır metal içeriklerinin ise kritik sınır değerlerin altında olduğu ve sağlık açısından bir risk taşımadığı saptanmıştır.

\section{Çıkar çatışması}

Yazarlar arasında herhangi bir çıkar çatışması yoktur.

\section{Yazarların katkı beyanı}

KK: Araştıma materyallerinde analizlerin yapılması ve makalenin yazımına katkıda bulunmuştur. ST: Araştırma materyallerinin temini ve makalenin yazımına katkıda bulunmuştur.

\section{Kaynaklar}

Baytop, T. 1999. Türkiye'de Bitkiler İle Tedavi (geçmişte ve bugün). Nobel Tıp Kitabevi, ISBN: 975-420-0211 , İstanbul.

Bolat, İ., Kara Ö. 2017. Bitki besin elementleri: Kaynakları, işlevleri, eksik ve fazlalıkları. Bartın Orman Fakültesi Dergisi, 19(1), 218-228.

Davis, P.H. 1965-1988. Flora of Turkey and the East Aegean Island. Vol: 1-10, Edinburgh: Ediburgh University Press.

Davis, P. H., 1965-1985. Flora of Turkey and East Aegean Islands, vol. 1-9. Edinburg University Press, Edinburgh.

Davis, P. H., Mill, R.R., Tan, K., 1988. Flora of Turkey and East Aegean Islands vol. 10 (suppl. 1). Edinburg University Press, Edinburgh.

Ergün, N., Yolcu, H., Karanlık, S., Dikkaya, E. 2010. Amanoslar'da (Hatay) yetișen bazı bitki türlerinde ağır metal birikimi ve mineral içerik üzerine bir çalışma. Research Journal of Biology Sciences, 3(2), 121-127.

Erzurumlu, G.S., Söğüt, Z. 2012. Doğu Akdeniz Bölgesi'nde Doğal Salep Türlerinin Saptanması Ve Mikorizaların Belirlenmesi Üzerine Araștırmalar. Türkiye 2. Orkide ve Salep Çalıștayı. ETAE Yayın No: 153 , s 99-124

Esetlili, B. C., Pekcan, T., Çobanoğlu, Ö., Aydoğdu, E., Turan, S., Anac, D. 2014. Essential plant nutrients and heavy metals concentrations of some medicinal and aromatic plants. 
Rout, G. R., Sahoo, S. 2015. Role of iron in plant growth and metabolism. Reviews in Agricultural Science, 3, 124.

Güner, A., Aslan, S., Ekim, T., Vural, M., Babaç, M.T. 2012. Checklist of the Turkish Plants (Vascular Plants). Publishing of Nezahat Gökyiğit Botanical Garden and Flora Researches Association. İstanbul.

Hürkan, K., Yüksel, M. B., Hürkan, Y. K., Demir, N. 2019. Determination of total phenolic and flavonoid contents, antioxidant and antimicrobial activities of some important salep orchids. Eskișehir Teknik Üniversitesi Bilim ve Teknoloji Dergisi-C Yaşam Bilimleri ve Biyoteknoloji, 8(2), 191-202.

Kacar, B., İnal, A. 2010. Bitki analizleri. Nobel Yayın Dağıtım.

Kırlı, A., Korkmaz, K., Kara, Ş.M., Dede, Ö., Akgün, M. 2019. Effects of pre-storage calcium applications on physical and chemical attributes of potato. Akademik Ziraat Dergisi, 8(2), 313-318.

Korkmaz, K. Ibrikci, H. Karnez, E. Buyuk, G. Ryan, J. Ulger, A.C. Oguz H. 2009 Phosphorus Use Efficiency of Wheat Genotypes Grown in Calcareous Soils, Journal of Plant Nutrition, 32:12, 2094-2106,

Korkmaz, K., Kara, S. M., Ozkutlu, F., Gul, V. 2010. Monitoring of heavy metals and selected micronutrients in hempseeds from North-western Turkey. African Journal of Agricultural Research, 5(6), 463-467.

Korkmaz, K., Dede, Ö., Erdem, H., Çankaya, S., Akgün, M. 2015. Relationships between chemical and physical properties of soils and nutrient status of plants on yield of potato. Fresenius Environmental Bulletin 24, 4108-4113.

Laroche, V., Pellerin, S., Brouillet, L., 2012. White Fringed Orchid as İndicator of Sphagnum bog integrity. Ecological Indicators, 14 (1), 50-55

Okut, N. 2019. Van İlinden Seçilmiş Bazı Tıbbi Bitkilerin Ağır Metal İçerikleri. Iğdır Üniversitesi Fen Bilimleri Enstitüsü Dergisi, 9(1), 533-544.

Özcan, M. M., Dursun, N., Juhaimi, F. A. 2013. Macro-and microelement contents of some legume seeds. Environmental monitoring and assessment, 185(11), 9295-9298.

Özkutlu, F., Korkmaz, K., Akgün, M., Ete, Ö. 2016. Magnezyum gübrelemesinin findığın (Corylus avellana L.) verim ve bitki besin elementi içeriklerine etkisi. Ordu Üniversitesi Bilim ve Teknoloji Dergisi, 6(2), 48-58.
Palaz, E. B., Yılmaz, C. H., Aytop, H., Büyükçıngıl, Y. 2018. Kahramanmaraş doğal florasında yetișen salep orkide bitkisinin mineral beslenme özellikleri ile yetiştiği toprakların bazı fiziksel ve kimyasal özelliklerinin incelenmesi. Türk Tarım ve Doğa Bilimleri Dergisi, 5(4), 537-544.

Petrova, S. 2011 Biomonitoring study of air pollution with Betula pendula Roth. Plovdiv, Bulgaria. Ecologia Balkanica, 3 (1), 1-10.

Rajan, J.P., Singh, K.B., Kumar, S., Mishra, R.K. 2014. Trace elements content in the selected medicinal plants traditionally used for curing skin diseases by the natives of Mizoram, India. Asian Pacific journal of tropical medicine, 7, S410-S414.

Sekeroglu, N., Ozkutlu F, Kara SM, Ozguven M 2008. Determination of cadmium and selected micronutrients in commonly used and traded medicinal plants in Turkey. Journal of The science. of Food and Agriculture. 88: 86-90.

Sevilmiş, U., Sevilmiş, D., Ölmez, Y.A., Aykanat, S., Özcan, O.B. 2020. Soyada Bitki Besleme ve Hastalıklarla Mücadele Yöntemi Olarak Yapraktan Mangan Uygulamaları. Ziraat Mühendisliği, (369), 4-21.

Singh, R. 2020. Calcium in plant biology: nutrient and second messenger. International Journal of Biological Innovations, 2(1), 31-35.

Tatiya, A., Kalaskar, M., Patil, Y., Surana, S. 2018. Chemical analysis, nutritional content and antioxidant property of Eulophia herbacea Lindl. tubers: a medicinally versatile Indian tribal nutritional food supplement.

Tekinșen, K.K., Güner, A. 2010. Chemical composition and physicochemical properties of tubera salep produced from some Orchidaceae species. Food Chemistry, 121(2), 468-471.

Tonguç, M., Şanlı, A., Karakurt, Y., Ünlü, H. 2017. Fasulyede Kükürt Uygulamalarının Verim ve Verim Öğeleri Üzerine Olan Etkilerinin Belirlenmesi. Bahçe Kültürleri Araştırma Enstitüsü Adına Sahibi, 44.

Yaldız, G., Şekeroğlu, N. 2013. Tıbbi ve aromatik bitkilerin bazı ağır metallere tepkisi. Turkish Journal of Scientific Reviews, 6(1), 80-84.

Yaman, K. 2012. Batı Karadeniz Bölgesinde Salep Ticaret Yapan Aracı-Komisyoncu Firmalar Hakkında Bir Araştırma: Kastamonu Ve Safranbolu Örneği, Türkiye 2. Orkide ve Salep Çalıştayı ETAE Yayın No: 153, s 11-23. 
Yazıcı, D., Korkmaz, K. 2020. Karabuğday bitkisinde bor alınımı ve toksitesi üzerine potasyum uygulamalarının etkisi. Akademik Ziraat Dergisi, 9(1), 151-162. 